\title{
PLURALITAS DAN RELASI ANTAR AGAMA Analisis Struktural Relasi \\ Kelompok Agama Antara Islam dan Katolik di Desa Caluk Kecamatan Slahung Kabupaten Ponorogo
}

\author{
A.B Musyafa Fathoni, Ahmad Lutfi, Ahmad Nu'man Hakiem, dan \\ Ahmad Faruk
}

\begin{abstract}
Abstrak:
Penelitian ini diawali dari kegelisahan akademik penulis adalah bagaimana bisa agama yang pada asalnya mempunyai klaim kebenaran yang sifatnya primordial menjadi kebenaran yang sifatya universal. Berangkat dari kegelisahan akademik tersebut maka penelitian ini dilakukan dengan memfokuskan pada norma dan lembaga sosial yang mengikat mereka, dimana hal tersebut menjadikan harmonisasi kehidupan beragama. Darifokus penelitian ini maka ada beberapa masalah yang dibahas; pertama, bentuk norma-norma yang ada yang menjadikan pemahaman agama masyarakat menjadi universal dan sekaligus juga primordial di desa Caluk tersebut. Kedua, bentuk lembaga sosial yang mewadahi norma-norma universalitas dan primordialitas agama masyarakat desa Caluk. Untuk membahas ini kami menggunakan pendekatan sosiologi dengan memanfaatkan teori fakta sosial Emile Durkheim. Tujuan dari masalah yang pertama adalah mendeskripsikan norma dan tujuan dari masalah yang kedua adalah mendeskripsikan lembaga sosial. Dari dua pembahasan tersebut disimpulkan bahwa norma yang mengubah sifat primordialitas agama ada tiga, yakni norma susila, kesopanan, dan agama. Sedangkan wadah norma tersebut adalah lembaga pemerintah dan agama.
\end{abstract}

Kata kunci: Primordialitas, universalitas, norma, dan lembaga sosial.

\section{PENDAHULUAN}

Bermula dari observasi awal penulis tentang relasi yang ada pada komunitas muslim dan non muslim di Desa Caluk. Kondisi yang ada pada desa tersebut tampak adanya komunitas yang hidup 
berdampingan, dimana dari segi keyakinan mereka berbeda-beda, yakni muslim dan non muslim. Bahkan ada sebelas keluarga, yang suami dan istrinya berbeda keyakinan. Relasi antar sesama pemeluk agama yang berbeda adalah bagian dari keseharian mereka dan bukan persoalan yang krusial. ${ }^{1}$ Ini adalah fenomena yang menarik untuk dikaji lebih mendalam karena, bagaimana bisa agama yang pada asalnya mempunyai klaim kebenaran yang sifatnya primordial menjadi kebenaran yang sifatnya universal?.2

Secara teoritis, agama punya kandungan nilai yang mengikat dan melahirkan solidaritas primordial. Bentuk solidaritas primordial tersebut termanifestasi dalam perspektif yang muncul dalam agama seperti bentuk sentimen insider dan outsider. ${ }^{3}$ Hal ini logis karena dalam agama ada yang disebut dengan kebenaran absolut dan bersifat "not falsified postulation". ${ }^{4}$ Selain solidaritas primordial antar agama, solidaritas primordial internal agama juga biasa terjadi. Contoh kasus dalam hal ini adalah dalam bentuk isu tentang takhayul, bid'ah, dan khurafat (TBC) yang marak dalam pertentangan antara Islam versi Arab dan Islam versi pribumi. Hal ini menunjukkan bahwa klaim kebenaran agama itu begitu kuat dan menjadi sifat dasarnya. Sifat itu menumbuhkan ikatan kelompok dan menjadikan mereka merasa benar. Sehingga dalam pandangan teori ini jika ada komunitas, yang mana kedua agama tersebut berdampingan, maka akan diasumsikan akan terjadi pemaksaan kebenaran satu dengan yang lain.

${ }^{1}$ Wawancara, 13 April 2017.

${ }^{2}$ Primordialitas agama misalnya ada ungkapan dalam al-Qur'an bahwa agama yang diterima di sisi Allah adalah agama Islam, (inna ad-dina 'inda a-Lahi al-Islam). Dalam agama katolik juga diemikian, bahwa "jalan kebenaran ada di dalam gereja" (ungkapan ini kami dengar secara lesan pemeluk agama Katolik dan bukan dari teks asli kitab suci mereka).

${ }^{3}$ Perpektif insider dan outsider dalam agama lihat Richard C. Martin (ed), Approaches To Islam In Religious Studies. Essay Richard C. Martin,"Islam And Religious Studies: An Introductory Essay" (U.S.A: The University Of Arizona Oress, 1985), Hal 1-19.

${ }^{4}$ Istilah ini kami pinjam dari Amin Abdullah dalam, "The Intersubjective Type of Religiosity:

A Contribution (a fresh Ijtihad) of Indonesian Islamic Studies to a Multicultural Society". Makalah yang dipresentasikan dalam forum AICIS ke IV di Balikpapan tahun 2014.

Fenomena sentimen tentang kebenaran absolut bagi agama, sebagai fakta ada pada kasus pemilihan gubernur Basuki Cahya purnama dan Anies Baswedan baru-baru ini. Dalam kasus tersbut muncul pertanyaan tentang keabsahan pemimpin yang bukan dari golongan non Islam (Basuki Cahya Purnama) untuk memimpin Gubernur. 
Kondisi warga desa Caluk di atas merupakan bantahan terhadap teori di atas, bahwa ternyata agama juga bisa menjadi universal. Kendati bisa saja agama mempunyai klaim kebenaran diri (truth claim) yang bersifat absolut, namun tetap saja selalu ada potensi bagi agama bisa menjadi kekuatan universal. Fakta universal agama tersebut ada dalam bentuk harmoni hidup secara berdampingan di desa tersebut. Hal ini mengingat komposisi jumlah penduduk yang ada di desa tersebut menunjukkan adanya kedua pemeluk agama yang berbeda. Komposisi jumlah penduduk beragama Islam berjumlah 1828 jiwa, 448 jiwa beragama Khatolik, 26 agama Kristen Protestan, dan 20 orang penganut aliran kepercayaan. ${ }^{5}$

Disamping adanya jumlah komposisi yang berbeda antara Islam dan Kristen, ada juga lembaga sosial yang dibentuk oleh masyarakat dalam bentuk "lembaga musyawarah desa". Anggota dari forum ini adalah Islam, Katolik, Kristen Protestan, dan Aliran kepercayaan. ${ }^{6}$ Forum ini punya aktivitas pemberdayaan ekonomi warga. Kemudian ada juga forum kerukunan umat beragama yang ditingkat kecamatan kota yang menjadi media interaksi antar umat beragama, dimana ada anggotanya berasal dari Caluk. ${ }^{7}$ Dari forum ini ada norma yang dipakemkan bersama sebagai peraturan hidup masyarakat setempat demi keberlangsungan hak beragama.

Dengan demikian, antara masing-masing pemeluk agama tidak menghiraukan klaim kebenaran primordial yang ada pada agamanya,

${ }^{5}$ Data ini diperoleh dari Data Potensi Desa Caluk Tahun 2000-2005. Kendati bisa saja data ini tidak akurat karena seringnya penduduk melakukan pindah agama untuk kebutuhan pernikahan, kemudian setelah usai menikah agama yang dianutnya berubah lagi ke agama asal. Karena sulitnya mendapat data yang asli dan akurat maka data ini kami jadikan pegangan sebagai sumber data utama karena fokus penelitian ini bukan pada aspek kuantitasnya jumlah pemeluk masing-masing agama. Data jumlah pemeluk perbedaan agama tersebut hanya sebagai pintu awal bagi penelitian sesungguhnya dalam karya ini. Kemudian data itu kami artikan sebagai representasi bagi adanya komunitas beda agama yang hidup berdampingan selama bertahun-tahun.

${ }^{6}$ Forum ini mempunyai agenda pertemuan setiap satu bulan sekali. Ketuanya adalah bapak Suwito. Masing-masing anggota dari forum masjid ini punya kewajiban iuran bulanan pada forum ini yang akan digunakan untuk bantuan modal kepada warga di sekitarnya yang dianggap membutuhkan modal. Bentuk modal selama ini yang pernah diberikan adalah kambing satu pasang, yang nantinya bila beranak keuntungannya akan diambil oleh pemelihara. Hasil wawancara dengan pak Wito pada tanggal 13-April 2017.

${ }^{7}$ FKUB di kecamatan Slahung ini adalah bentukan warga dan pemerintah untuk mengikat interaksi antar pemeluk agama yang berbeda agar tercipta kerukunan dalam hidup beragama. 
kendati bisa saja jumlah mayoritas Islam yang ada di desa tersebut mengalahkan minoritas dan menjadi hegemonik terhadapnya, namun fakta di desa tersebut ternyata tidak selalu demikian. Minoritas menjadi bagian dalam mayoritas dan terintegrasi di dalamnya. Bahkan bisa dikatakan minoritas Katholik dan mayoritas Islam membentuk satu koumunalitas relasi yang khas di dalamnya.

Dari ungkapan warga desa Caluk sebagaimana ada dalam redaksi di atas serta adanya lembaga sosial tempat terjadinya integrasi penduduk dalam satu desa, harmoni dalam bentuk hidup saling berdampingan selama puluhan tahun adalah contoh bahwa kebenaran absolut yang diyakini bisa melahirkan solidaritas primordial dan punya potensi disintegratif bisa terbantah. Di sisi yang lain, agama ternyata juga bisa menjadi kekuatan yang punya potensi universal dan menjadi media perekat bagi relasi antara agama. Bantahan terhadap primordialitas agama tersebut setidaknya bisa dibuktikan dalam lingkup kecil desa Caluk tersebut, dimana wujud universalitas agama dalam lingkup desa tersebut bisa dimaknai sebagai satu dalam keberbagaian dan keberbagaian dalam kesatuan tanpa menghilangkan eksistensi masing-masing dan membentuk "norma-norma" kehidupan sosial yang khas, yang menjadikannya tetap menyatu.

Dari pemaparan tentang latar belakang penelitian di atas, maka fokus penelitian ini adalah pada norma-norma dan lembaga-lembaga sosial yang mewadahinya. yang ada kaitannya dengan fenomena universalitas agama. Norma dan lembaga sosial yang akan digali dalam penelitian ini adalah norma yang menuntun perilaku sosial hingga universalitas agama itu terbentuk. Kemudian lembaga sosial adalah penjaga norma juga sebagai wadah bagi adanya pembakuan norma tersebut. Oleh karena itu rumusan masalah yang akan diangkat dalam penelitian ini adalah: Pertama, bagaimana bentuk norma-norma yang ada yang menjadikan pemahaman agama masyarakat menjadi universal dan sekaligus juga primordial di desa Caluk tersebut? kedua, apa bentuk lembaga sosial yang mewadahi norma-norma universalitas dan primordialitas agama masyarakat desa Caluk?

Dari kedua fokus masalah yang ada di atas maka tujuan penelitian ini adalah menggali norma-norma dan lembaga sosialnya, 
yang menjadikan agama berubah dari primordial menjadi universal. Dalam pengalian norma itu akan ditelusuri beberapa hal sebagai berikut: Pertama, mendeskripsikan norma-norma yang dipakai dalam kehidupan sosial masyarakat desa Caluk yang telah mengubah primordialitas agama menjadi universal. Kedua, mendeskripsikan bentuk-bentuk lembaga sosial yang menjadi wadah bagi normanorma universalitas dan primordialitas agama.

Adapaun manfaat yang diharapkan dalam penelitian ini ada dua hal, yakni manfaat secara teoritis dan praktis. Manfaat teoritisnya, penelitian ini diharapkan bisa turut serta mengembangkan wawasan keilmuan dalam karya ilmiah, khususnya menyangkut tentang kehidupan beragama di Indonesia yang memang keragaman agama menjadi kultur utamanya. Adapun manfaat praktisnya bisa bagi peneliti sendiri dan juga bisa bagi masyarakat. Bagi peneliti adalah untuk pemetaan demografi dalam membangun kerukunan beragama. Di sisi yang lain, karya ini juga diharapkan bisa memberi kontribusi bagi pemikiran lainnya mengenai kehidupan beragama di Indonesia yang pernah diteliti sebelumnya. Sedangkan bagi masyarakat diharapkan mampu menyusun strategi dalam mempertahankan kehidupan harmonis antara pemeluk agama di desa Caluk.

Pendekatan dalam penelitian ini adalah adalah pendekatan sosiologi dengan paradigma fakta sosial. Adapun jenis penelitiannya adalah kualitatif. aspek kualitatifnya karena dalam penelitian ini jenis datanya adalah data verbal atau kata-kata dari beberapa informan yang akan kami wawancarai. Karena sifatnya mendeskripsikan dan datanya verbal maka jenis penelitian ini adalah deskriptifkualitatif. Prosesnya peneliti melakukan dialog obyek yang diteliti untuk memperoleh masukan informasi dan data lisan dan tulisan dan melakukan pencatatan lengkap dari masukan yang diperoleh tersebut. Data tersebut kemudian dinarasikan secara deskriptif. ${ }^{8}$ Hingga narasi deskriptif dari penelitian itu bisa mengungkap informasi tentang fokus penelitian. Pengungkapan tentang data tersebut akan digali dengan metode wawancara, observasi, dan dokumentasi tentang norma-norma yang sudah baku atau tepatnya dibakukan di desa tersebut hingga menuntun perilaku masyarakat

${ }^{8}$ Lexy J. Moleong, Metodologi Penelitian Kualitatif (Bandung: PT Remaja Rosdakarya, 2009), 4. 
untuk bertindak dan melahirkan fenomena agama universal di desa Caluk Kecamatan Slahung Kabupaten Ponorogo.

\section{PEMBAHASAN}

Proses pembentukan norma agama bisa dilihat dari ungkapan pak Sugianto, mantan ketua Persatuan Gereja Indonesia (PGI) yang sempat penulis wawancarai. Dalam ungkapannya, dia mengatakan: ${ }^{9}$ Saya sendiri tidak tahu mengapa saya harus Katolik. Katolik bagi saya bukan masalah pilihan tapi masalah rasa. Saya merasa bahwa dengan saya Katolik nyaman saja dan perasaan keberagamaan dan ketenangan nurani bisa saya rasakan. Dengan begitu, walau kami ini minoritas, kami tidak akan membalas apabila kami disakiti. Semua perilaku saya biar kepada Yang Maha Kuasa saja yang menjadi tujuan. Jadi ini merupakan keinginan agar kami ikhlas mas Lutfi.

Ungkapan yang menyatakan,"Katolik bukan masalah pilihan tapi masalah rasa" dan "saya merasa nyaman dan perasaan keberagamaan dan ketenangan nurani bisa saya rasakan" adalah satu titik yang bisa menjelaskan pembentukan norma agama ini. Ungkapan "ketenangan" dan "merasa nyaman" adalah satu ungkapan bahwa menjalani agama lebih merupakan persoalan rasa. Masalah rasa ini seperti sesuatu yang tidak bisa diketahui alasan argumennya. Sehingga ini bukan persoalan akal. Dengan demikian, dalam pergaulan sosial kemasyarakatan asal persoalan rasa ini tidak diganggu dan tetap diberi ruang dalam pelaksanaanya, maka rasa solidaritas sosial tetap akan muncul.

Dalam diri komunitas Katolik, persoalan rasa ini merupakan hal yang sifatnya subyektif. Adanya hal yang subyektif ini, tentu saja akan mengikat antara satu dengan yang lain dalam solidaritas eksklusif. Tapi solidaritas ini tidak mengarah kepada pembenaran diri yang eksklusif hingga menutup diri mereka untuk melakukan pergaulan sosial. Dalam pergaulan sosial mereka bisa dikatakan cukup cair dan mampu mengadaptasi lingkungan sosial mereka, hal itu karena dalam pergaulan sosial di lingkungan desa Caluk itu tidak mempersoalkan masalah kebenaran rasa tersebut. Sehingga dalam masalah tersebut mereka cukup bisa beradaptasi dengan lingkungannya kendati dalam lingkungan tersebut persoalan rasa

${ }^{9}$ Wawancara, 02 Agustus 2017. 
kebenaran ada yang berbeda-beda. Sehingga masalah norma sosial, dalam agama Katolik ini mereka bisa mengikuti dan mengadaptasi sebagaimana yang lain.

Dalam ungkapan pak Sugianto mengenai golongan yang memaksakan kebenaran rasa ini, ada petikan wawancara sebagaimana berikut ini: ${ }^{10}$

Jika saja ada umat yang mencoba memaksakan kebenaran agama kepada yang lain, atau umat yang ekstrem dalam hal kebenaran, biasanya pasti ada kepentingannya mas. Mereka biasanya menyimpan sesuatu dibalik apa yang dibawanya. Saya tidak suka hal tersebut. Bahkan saya pasti akan menjauhinya dan tidak bergaul dengan mereka. Bahkan bisa juga mereka itu tidak ikhlas. Saya sendiri menghindari hal itu, bahkan umat Katolik yang ada di sini juga. Karena itu banyak umat di sini yang membiarkan dalam satu keluarga beda agama. Hal itu tidak menjadi persoalan.

Ungkapan ini cukup menegaskan bahwa menjadi agamawan, adalah persoalan merasakan kebenaran. Jika saja hal merasakan kebenaran itu harus dikeluarkan dan harus diikuti oleh orang lain, maka kebenaran yang dia bawa itu pasti ada tujuan-tujuan selain persoalan rasa tersebut. Bisa jadi kerena kepentingan duniawi atau lainnya, yang menyangkut hal-hal yang menjadi bagian dari kalkulasi rasional. Oleh karen itu, kebenaran tersebut bukan bagian dari agama lagi.

Bagaimana hubungan rasa kebenaran yang dirasakan oleh umat agama Katolik tersebut dengan masalah norma yang ada? Dalam hal ini, persoalan rasa kebenaran adalah bagian dari persoalan norma susila. Jadi lebih tepatnya, pembentukan norma yang berbasis agama Katolik adalah norma susila tersebut. Dalam norma ini, masalah rasa mendapatkan definisinya.

Bentuk norma agama yang dikembangkan oleh umat ini adalah bentuk solidaritas rasa. Namun solidaritas ini bisa bermakna ganda. Di satu sisi ia membentuk solidaritas eksklusif dalam internal agama, di sisi yang lain bisa berpotensi untuk menjadi solidaritas inklusif ketika berhadapan dengan komunitas agama di luar diri mereka. Solidaritas eksklusif maknanya membentuk kesatuan internal dalam keberagamaan mereka antar sesama Katolik. Bahkan bisa juga

${ }^{10}$ Wawancara, 02 Agustus 2017.

Kodifikasia, Volume 11 No. 1 Tahun 2017 
dikatakan solidaritas sambung rasa. Hal itu karena dalam internal agama ini ada perasaan-perasaan kebenaran yang sama.

Sedangkan bentuk solidaritas inklusifnya adalah tidak adanya dorongan dari dalam rasa kebenaran itu untuk memaksakan kebenaran kepada pihak yang lain. Pembentukan solidaritas inklusif ini menjadikan mereka terbuka kepada umat yang lain dalam pergaulan sosial. Sehingga kebenaran eksklusif itu tidak sampai keluar dan dipaksakan kepada yang lain.

Dengan demikian dalam norma susila dari agama Katolik ini juga punya kontribusi terhadap semangat universalisme agama. Primordialitas dalam bentuk rasa kebenaran tetap diberi ruang eksistensinya, dalam waktu yang bersamaan kebenaran rasa itu juga dilarang untuk dikeluarkan sebagai kebenaran yang dipaksakan. Larangan untuk mengeluarkan kebenaran rasa yang bersifat primordial ini menjadi rahim dari lahirnya universalitas agama. Sehingga primordialitas agama tersebut menjadi pendukung juga dengan pembentukan norma-norma yang lain.

Jika solidaritas eksklusif tetap ada dan primordialitas itu juga demikian, bagaimana bentuknya primordialitas tersebut. Dalam ruang apa bentuk primordialitas itu muncul. Untuk menjawab masalah ini, ada petikan wawancara yang bisa diungkap untuk menjawab masalah tersebut, yakni: ${ }^{11}$

Ajaran agama Katolik itu diberikan sedini mungkin supaya menjadi benteng anak itu sendiri. Bentuk ajaran yang diberikan antara lain iman, akhlak, moral, dan cerita-cerita yang ada dalam alKitab yang dibacakan kepada keluarga dan anak-anak. Cerita-cerita ini supaya menjadi keyakinan dan menambah wawasan agama agar anak dan keluarga punya iman yang mantap.

Ungkapan yang menyatakan, "agar menjadi benteng bagi si anak dan keluarga itu sendiri” adalah bentuk dari primordialitas. Namun primordialitas ini hanya dalam bentuk keluarga alias privat saja. Sedangkan dalam ruang publik tidak demikian halnya. Hal ini sebagaimana dalam ungkapan pak Sugianto itu sendiri yang mengatakan bahwa ajaran katolik itu agar menjadi benteng bagi anak dan keluarga.

${ }^{11}$ Wawancara, 9 Agustus 2017. 
Gereja keluarga adalah menifestasi dari semangat primordialitas. Kendati ia kecil tapi semangat gereja besar juga terdapat dalam semangat gereja kecil. Sehingga ajaran primordialitas gereja besar tetap dijaga dalam gereja kecil itu.

Ungkapan dari pak Suroyo ini juga diperkuat oleh keluarga Katolik lainnya. Kelurga lainnya itu adalah keluarga pak Boimin. Ungkapannya yang menjelaskan tentang primordialitas agama ini sedikit menjelaskan pula pembedaan antara universalitas yang mendukug terhadap solidaritas inklusif dan primordialitas yang mengarah pada soldiratis eksklusif. Sehingga antara dua soldaritas ini terlihat seperti bertentangan namun ternyata tidak dan menemukan ruangnya sendiri-sendiri. Dalam ungkapan pak Boimin: ${ }^{12}$

Keluarga katolik itu sangat besar pengaruhnya untuk menjaga masalah ajaran agama. Sebab keluarga itu ada ikatan-ikatan khusus kepada Dzat Tuhan yang Maha Esa. Ikatan-ikatan khusus itu ya anak, bapak, dan ibu. Ikatan khusus niku sifate khusus. Beda ikatan antara saya dan anda serta tetangga. Ikatan saya dan anda ya hanya teman, demikian juga saya dan tetangga. Beda lagi saya dengan saudara-saudara saya, seperti saya dengan adik saya, bibi, paman, dan yang lainnya. Ikatan saya dan saudara itu hamper sama dengan antara saya dan anda tapi lebih dekat lagi. Saya dan keluarga itu ada janji lan kewajiban yang sifatnya suci itu tadi. Maka ajaran Katolik itu utamanya ya kepada keluarga. Untuk saya dan anda dan dengan saudara-saudara tadi yang sifatnya saling menghormati umpama ada perbedaan antara kita dan lainnya.

Ungkapan pak Boimin ini lebih menjelaskan tentang masalah relasi privat dan publik antar individu. Relasi ini menjadi alasan dimana ajaran itu tetap dijaga. Hal ini sebagaimana dalam ungkapan Islam sendiri bahwa yang pertama harus dijaga adalah diri dan keluarga, sebagaimana ungkapan al-Qur'an, "jagalah diri dan keluargamu dari api neraka”. Demikian juga dalam agama Katolik, bahwa menjaga keyakinan itu tetap keluarga dahulu yang harus dibina. Sehingga semangat primordial agama itu sesuatu yang utama dalam keluarga. Adapun di luar keluarga relasi itu telah berubah ke masalah publik dan oleh karenanya primordialitas itu berganti arah ke universalitas.

${ }^{12}$ Wawancara, 09 Agustus 2017.

Kodifikasia, Volume 11 No. 1 Tahun 2017 
Dalam pembentukan norma agama berbasis Islam ini, ada ungkapan menarik dari ungkapan seorang takmir Mujahidin desa setempat. Dia mengatakan: ${ }^{13}$

Untuk urusan agama itu urusan masing-masing. Kalau ada keluarga yang beda agama dalam satu rumah hal itu biasa di sini mas. Apakah terjadi konflik di dalamnya hal itu urusan masing-masing-masing. Tapi selama ini kehidupan mereka biasa-biasa saja dan tidak terjadi ketegangan di dalamnya. Rukun-rukun saja mas. Lihat mereka itu (waktu Maghrib) ada yang berangkat ke gereja dan ada yang berangkat ke masjid. Malah mereka saling bertegur sapa di jalan. Jika ada yang mempermasalahkan agama orang lain justru malah tabu (saru. Jawa). Islam mengurusi Islam sendiri dan juga Katolik juga mengurusi sendiri agamanya. Tapi dalam sosial kemasyarakatan ya harus bersama.

Dalam ungkapan tersebut ada pemilahan secara jelas dalam soal mengatur kehidupan mereka, yang menyangkut aspek agama, aspek sosial, dan aspek yang lain. Dalam soal agama adalah soal privat. Sedangkan dalam soal sosial kemasyarakatan dan sosial politik adalah soal publik. Kedua bidang ini tidak dicampur aduk menjadi satu.

Namun bisa menjadi catatan dalam hal ini bahwa urusan agama adalah urusan privat. Dalam urusan privat ini dorongan primordialisme agama dijaga agar tidak keluar dari ruang privatnya. Bahkan dorongan primordial ini jika sampai keluar bisa menjadi tabu (saru. Jawa). Tabunya membawa dorongan primordial Islam ini adalah satu bentuk norma itu sendiri, yang mana menjadi krakter khas norma Islam. Sehingga dalam relasi sosial, aspek agama tidak pernah menjadi isu publik yang bisa dimainkan untuk memperhadapkan antara kedua agama tersebut.

Ini bisa dibuktikan dari pergaulan sehari-hari mereka, sebagaimana ungkapan,"lihat mereka itu (waktu maghrib) ada yang berangkat ke gereja dan ada yang berangkat ke masjid". ${ }^{14}$ Dalam kasus tersebut, perbedaan agama tidak menjadi persoalan, kendati keduanya tampil berhadapan. Hal ini juga bermakna bahwa kesalehan individu tetap mendapatkan ruang untuk diaktualisasikan tanpa ada intimidasi.

Kemudian untuk urusan publik seperti sosial dan politik, juga mengindikasikan tidak ada gejala primordialisme agama tampail

\footnotetext{
${ }^{13}$ Wawancara, 15 Agustus 2017.

${ }^{14}$ Wawancara, 15 Agustus 2017.
} 
dalam ruang publik. Hal tersebut seperti tidak adanya partai berlabel Islam yang dominan dalam proses pendulangan suara, seperti Partai Amanat Nasional (PAN), Partai Kebangkitn Bangsa (PKB), Partai Keadilan Sejahtera (PKS), atau Partai Bulan Bintang (PBB), yang mana notabene sebagai partai berbasis Islam. Rata-rata pemilih lebih melihat pada figur tokoh yang sedang melakukan kampanye dari pada setia terhadap militansi agama. Hal itu pun juga terkait dengan janji yang diberikan oleh calon daripada melihat pada agama figur.

Kendati agama agama itu punya sifat dasar primordial, namun ada temuan-temuan menarik lainnya yang ada di lapangan, yang sekiranya merupakan fenomena unik. Temuan ini berkaitan dengan merambahnya universalitas agama yang masuk dalam ruang privat. Sehingga penjagaan primordialitas agama yang dijaga dalam ruang privat, seperti keluarga, tidak terjadi. Temuan ini sebagaimana ada sekitar sepuluh keluarga, dimana kedua agama itu dipeluk oleh ayah, ibu, dan anaknya. Dalam soal ini ada petikan wawancara yang bisa kami sajikan dan akan kami jelaskan mengapa fenomena beda agama atau universalitas agama itu bisa masuk dalam ruang privat.

Temuan ini sebagaimana ada dalam wawancara kami dengan pak Suwandi yang dalam keluarganya mempunyai dua agama. Pak suwandi memeluk agama Islam dan istrinya bu Suratin beragama Katolik. Kemudian keluarga ini mempunyai tiga anak yang kesemuanya beragama Katolik. Dalam suatu wawancara ini pak Suwandi mengatakan tentang masalah agama dalam ungkapannya: ${ }^{15}$

Keluarga saya ini tidak mempermasalahkan tentang agama yang berbeda. Saya sendiri agamanya Islam dan istri saya beragama Katolik. Putra kami yang jumlahnya tiga agamanya ikut ibunya. Saya tidak mempermasalahkan anak saya ikut agama ibunya apa agam saya. Semua itu saya serahkan kepada anak-anak sendiri. Dan semua di keluarga ini rukun saja walaupun agamanya berbeda-beda. Saya dan istri saya menganggap bahwa agama itu sama. Islam mengajarkan kebaikan demikian juga agama Katolik. Di Islam mengajarkan akhlak yang baik, dan demikian juga di katolik. Ini kan berarti sama saja. Makanya selaku orang tua, kami mendukung aja apa yang menjadi kegiatannya sendiri-sendiri. Pada waktu bulan kemarin, pada waktu puasa romadlon istri saya juga mengingatkan ketika waktunya sahur dan puasa romadlon. Kemudian waktunya gereja. Yang penting keluarga ini diberi kesahatan aja.

${ }^{15}$ Wawancara, 15 Agustus 2017.

Kodifikasia, Volume 11 No. 1 Tahun 2017 
Petikan wawancara ini merupakan fenomena masuknya universalitas agama yang masuk dalam ruang privat keluarga. Dalam ungkapan pak Suwandi sendiri bahwa agama itu merupakan ajaran kebaikan. Sisi universalitas agama ini menjadikannya tidak mempermasalahkan tentang persoalan beda agama. Sehingga keragamaan agama dalam suatu keluarga ini bukan persoalan utama. Hal ini tentu berbeda dengan data wawancara yang ada di atas, bahwa menjaga agama itu yang terpenting adalah keluarga dulu. Tapi berbeda dengan keluarga ini.

Dari segi cara pandangnya terhadap agama, pak Suwandi menangkap gagasan universal agama, yakni semua agama mengajarkan kebaikan, baik itu Islam sendiri atau Katolik. Kebaikan dalam hal ini adalah kebaikan budi pekerti dimana dalam kedua agama mengajarkan untuk saling menghormati, berakhlak mulia, dan sopan santun. Di kedua agama juga mengajarkan untuk saling menghormati, dan juga mengajarkan tentang rukun sesame orang lain. Aspek universalitas ini yang ditangkap olehnya.

Berkebalikan dengan keluarga pak Suwandi, adalah keluarga pak Misdi. Jika pak Suwandi tadi agamanya Islam dan istrinya Katolik serta anaknya yang jumlahnya tiga beragama seperti ibunya, maka dalam keluarga pak Misdi ini bapaknya beragama Islam, istrinya bu Tukiyem beragama Katolik, tapi ketiga anaknya beragama Islam. dalam petikan wawancara dengan pak Misdi ini, dia mengungkapkan: ${ }^{16}$

Saya dan istri saya itu saling mengisi kekurangan masing-masing mas. Yang penting bagaimana baiknya. Saya juga mengajar ngaji anak-anak. Mengaji, puasa, wudlu ya saya yang mengajarkan kepada mereka. Adapaun ibunya mengajarkan anak tatakrama dan sopan santun. Pokonya gimana kerukunan itu bisa terjadi walaupun masalah agama itu berbeda-beda. Jika nanti dipersoalkan ya nanti tidak rukun dan kasihan anaknya.

Ungkapan ini tidak menyinggung masalah universalitas agama sebagaimana dalam keluarga pak Suwandi. Aspek yang ditekankan adalah oleh kedua orang tua tersebut adalah kerukunan. Aspek rukun ini menjadi perekat penting yang mana perbedaan agama dalam keluarga tidak dipersoalkan. Kendati bisa saja kerukunan itu menjadi nilai universalitas agama, tapi tidak demikian halnya denga keluarga pak

${ }^{16}$ Wawancara, 15 Agustus 2017. 
Misdi ini. Dalam ungkapan pak Misdi, kerukunan itu tidak didorong oleh semangat agama, melainkan oleh dorongan menghindari perpecahan rumah tangga dan nasib kedua anaknya jika orang tuanya berpisah. Berbeda dengan keluarga pak Suwandi. Dalam ungkapan pak Suwandi di atas, kerukunan itu bagian dari agama. Hal ini sebagaimana dikatakan sendiri olehnya dalam ungkapan, bahwa "semua agama itu mengajarkan kebaikan”. Dalam ungkapan "semua agama itu mengajarkan kebaikan" itu mengindikasikan bahwa semangat universalitas itu didorong oleh semangat agama. Minimal dari agama yang dia pahami.

Dari fenomena dua keluarga dari sepuluh keluarga yang berbeda agama tesebut, bagaimana sejatinya persoalan universilatias yang awalnya ada dalam ruang publik tapi masuk dalam ruang privat keluarga. Untuk menjawab persoalan ini, tidak bisa dilepaskan dari sejarah desa.

Hal ini bisa ditelusuri dari perkembangan Islam di desa Caluk tersebut. Di desa ini, masjid pertama dibangun pada masa pemerintahan desa pak Wakidi (1970-2001). Tepatnya pada tahun 1980-an. Pada masa sebelumnya, pengajaran agama berada di balai desa Caluk. Pelaksanaan ibadah umat Islam pada masa sebelum adanya masjid berada di balai desa Caluk. Ibadah ini berupa do'a bersama dan pengajian yang sifatnya masih umum dan belum menyentuh aspek pengetahuan yang mendalam tentang agama. Bahkan bisa dikatakan ini awal tahun 1980an merupakan babak baru agama Islam untuk dikembangkan lebih lanjut dengan adanya pembangunan tempat ibadah bersama.

Setelah berdirinya masjid, bentuk pendidikan awal yang diberikan adalah belajar mengaji, seperti taman pendidikan al-Qur'an (TPQ) dan madrasah untuk anak-anak. Obyek dari pendidikan seperti ini adalah anak-anak. Sedangkan orang tua yang menjadi orang tua anak-anak yang sedang belajar di TPQ dan madrasah belum kenal pengetahuan Islam secara mendalam. Oleh karena itu Islam belum menjadi pedoman hidup mereka. Bahkan bisa dikatakan Islam masih sebagai baju luar belaka. sehingga generasi lama atau sebelum tahun 1980-an belum menjadi obyek pendidikan yang dinaungi oleh perkembangan pendidikan yang ada di masjid tersebut. Oleh karena itu bisa dikatakan mereka masih abangan. ${ }^{17}$

${ }^{17}$ Tentu saja mengatakan mereka dengan status abangan ini problematic. Tapi kami tidak bermaksud memberikan status pejorative (merendahkan) kepada mereka. Istilah ini kami pakai hanya sebagai identitas perkembangan Islam saja antara sebelum tahun 1980-an dan setelah tahun tersebut. 
Hal yang bisa mendukung terhadap penjelasan ini adalah tingkat pendidikan mereka dan usia. Dari tingkat pendidikan, terwawancara tidak mengenyam pendidikan diluar dunia pendidikan yang ada di desa tersebut. Selain itu, rata-rata adalah tamat dari sekolah tingkat atas (SLTA) ke bawah. Dari pendidikan ini, mereka hanya mendapat pendidikan agama satu kali dalam satu minggu. Kemudian dari sisi usia, mereka adalah golongan yang sudah berusia limapuluh tahun ke atas. Di usia ini, jika dikaitkan dengan berdirinya masjid tahun 1984-an, maka pada waktu itu dia masih berusia sekitar tiga puluh tahun. Ini berarti pada usia SLTP dan SLTA, pendidikan agama yang dia peroleh masih berada di balai desa, yang kami sebut sebagai pendidikan agama yang masih bersifat permukaan saja. Sedangkan pendidikan agama yang ada di masjid, seperti TPQ dan madrasah, baru ada sekitar tahun 1990-an ke atas. Dari tahun itu mereka sudah berusia 40 tahun. Sedangkan anak didik yang sekolah di dua lembaga pendidikan tersebut adalah untuk anak-anak usia 6-12 tahun. Oleh karena itu mereka bukan menjadi bagian lagi dari perkembangan pendidikan Islam yang ada di desa Caluk tersebut.

Jadi bisa dikatakan bahwa mereka adalah produk generasi sebelum tahun 1980-an dimana pengajaran agama masih ada di balai desa setempat. Karena pendidikan masih berada di balai desa, dan pendidikanya hanya bersifat permukaan itu maka tingkat pemahaman Islam juga masih permukaan. Oleh karena demikian ini maka bisa dikatakan jumlah sepuluh keluarga yang ada di desa tersebut adalah keluarga yang menjadi sisa-sisa generasi sebelum tahun 1980-an. Sehingga semangat primordialitas agama yang harus dijaga dalam lingkup privat seperti keluarga tidak menjadi persoalan utama.

Dengan demikian, dalam kasus rumah tangga beda agama tersebut agama belum menjadi perhatian penting dalam kehidupan mereka. Namun setelah perkembangan Islam di desa tersebut telah mencapai perkembangan yang memadai, aspek primordialitas agama yang masuk dalam ruang privat seperti keluarga, menjadi persoalan penting dan tetap dijaga eksistensinya agar tetap berada dalam ruang privat tersebut.

Setelah membahas data tentang norma yang ada di masyarakat Caluk dalam lingkup keluarga dan agama, sekarang kita akan beralih 
ke norma-norma lain dalam kehidupan warga Caluk. Norma lain ini kami gali dari beberapa sumber, yakni kepala desa dan perangkat lainnya. Kedua wawancara ini kami lakukan secara terpisah. Diantara ungkapan-ungkapan yang bisa ditemukan dalam kaitannya tentang norma ini antara lain:

Setelah melalukan wawancara dengan kepala desa setempat berikut kami kutip sebagian wawancara dengan kepala desa setempat: Masyarakat di sini rukun mas, bila ada hajatan, seperti membangun rumah, dan tempat ibadah kami lakukan secara sambatan. Walaupun pemilik hajat membangun sudah punya kuli atau tukang untuk membangun rumah tapi para tetangga tetap membagi jadwal kerja membantu untuk meringankan yang punya hajat. Ini dilakukan baik oleh umat Islam ataupun umat katolik. Jadi antara kedua umat masingmasing saling bantu membantu dalam hal tersebut. Dalam diri kami tidak ada hambatan untuk saling membantu karena beragama itu yang penting rasa dalam hati. Walaupun kami berbeda agama tapi rasanya dalam hati tidak nyaman jika harus mempersoalkan. Oleh karena itu perbedaan itu kami anggap sebagai perbedaan tapi untuk membedabedakan tidak enak secara rasa. ${ }^{18}$

Ungkapan kepala desa tersebut bukan ungkapan yang sifatnya pribadi. Setelah kami melakukan dialog dengan beberapa responden dari masyarakat, seperti perangkat desa dan beberapa penduduk ternyata mengungkapkan hal yang sama, bahwa "perbedaan itu kami anggap sebagai perbedaan tapi untuk membeda-bedakan tidak enak secara rasa". Jadi pendorong adanya universalitas adalah adanya perasaan kemanusiaan yang dirasakan dalam hati. Hal ini dimaklumi karena kehidupan sosial masyarakat antara satu dengan yang lain saling berdekatan dan ada ketergantungan hidup antara satu dengan yang lain. Bentuk relasi tersebut menyebabkan meraka merasa mengesampingkan persoalan agama dan mengutamakan masalah rasa. ${ }^{19}$

Universalitas agama yang didorong oleh persoalan rasa tersebut dalam kategori norma termasuk norma susila. Hal ini karena norma

${ }^{18}$ Wawancara, 02 Agustus 2017.

${ }^{19}$ Ada ungkapan menarik dari salah satu carik desa tersebut,"sing penting sehat dan seger kewararasan mas tinimbang geger masalah agama. (yang penting sehat wal afiat mas dari pada konflik tentang perbedaan agama). 
susila itu terbentuk berdasarkan hati nurani. ${ }^{20}$ Perasaan itu merata dalam masyarakat dan muncul dalam perilaku sosial. Bentuk perilakunya seperti "sambatan" jika ada hajatan dari penduduk sekitar mengenai membangun tempat ibadah dan pemukiman. Oleh karena itu dalam bidang sosial bentuk universalitas agama yang muncul pada perilaku individu-individu yang ada dalam masyarakat dibentuk oleh norma susila. Ketaatan masyarakat untuk hidup harmonis juga dibentuk dari norma susila tersebut.

Dalam hal ini norma agama muncul sebagai pemisah relasi mereka. Eksistensi norma tersebut mengakibatkan mereka harus menjalankan keyakinan masing-masing. Dalam posisi ini keyakinan muncul sebagai pemutus relasi sosial. Hal ini bisa dimaklumi bahwa eksistensi keyakinan dalam internal agama tidak bisa disatukan antara individu satu dengan yang lainnya. Eksistensi keyakinan dalam hati tersebut bersifat niscaya. Kemudian dari segi pelaksanaan ajaran agama juga mempunyai sumber doktrin yang berbeda, dimana Islam bersumber dari kitab sucinya demikian juga agama lain. Perbedaan sumber dan keyakinan tersebut mengakibatkan norma agama menjadi pemisah relasi, namun hal tersebut bersifat sementara saja karena berada dalam ruang-ruang yang sifatnya terbatas. ${ }^{21}$

Hal ini merupakan rahasia dibalik "harmonisasi" kehidupan orang jawa. Aspek konflik seringkali disembunyikan dan tidak tampil dalam narasi permukaan. Hal ini karena dalam kehidupan jawa lebih mementingkan persoalan rasa dari pada kebenaran-kebenaran diri dan tampil sebagai kontestasi kebenaran. Dalam budaya jawa, bisa jadi aspek sentimen pribadi dan keyakinan kebenaran primordial itu tetap ada, tapi kultur mereka lebih menyukai untuk menyimpan itu

${ }^{20}$ Elly M. Setiadi dan Usma Kollip, Pengantar Sosiologi....132-133.

${ }^{21}$ Inilah apa yang disebut oleh Charles J Adam dalam bukunya Richard C. Martin (ed), Approaches To Islam In Religious Studies. Essay Richard C. Martin,"Islam And Religious Studies: An Introductory Essay" (U.S.A: The University Of Arizona Oress, 1985), 1-19. Dalam perspektifnya, agama mendorong penganutnya untuk punya perpektif insider dan outsider. Perspektif ini seringkali muncul dalam kehidupan sosial dimana selalu ada kemungkinan munculnya truth claim (klaim kebenaran). Tapi perlu dicatat bahwa perspektif tersebut tidak selamanya berlaku karena dalam ruang sosial seringkali juga muncul norma yang lain yang membuat rasa truth claim tersebut meredam dengan sendirinya. Apalagi dalam kultur orang jawa bahwa tepo seliro dan andap asor lebih dominan dari pada sentimen keberagamaan. Bahkan dalam budaya jawa, model konflik dan ketegangan yang sifatnya berbeda pendapat secara terbuka lebih banyak dihindari. 
dan menampilkan sisi persamaan.22 Oleh karena itu norma susila begitu kuat keberadannya khususnya dalam kultur budaya jawa.

Dalam kondisi ini, munculnya keyakinan yang bersifat primordial wujudnya tetap ada. Tapi bentuk primordialitas agama tersebut, dalam kahidupan orang jawa, adanya hanya dalam ruangruang kecil, seperti dalam rumah dan tempat ibadah dimana acara tersebut dilaksanakan. Ketika mereka masuk dalam kehidupan bermasyarakat maka norma susila hadir kembali dan menekan munculnya primordialitas tersebut.

Dalam kondisi ini persoalan norma memiliki ruang-ruang tersendiri. Untuk relasi sosial dan bermasyarakat maka keberlakuan norma susila nyata keberadaannya. Sementara untuk norma agama, kendati ia juga nyata tapi ruangnya kecil dan terbatas pada rumahrumah penduduk dan tempat-tempat ibadah. ${ }^{23}$

Proses penguatan norma susila di masyarakat caluk juga muncul dalam kegiatan-kegiatan desa. Salah satu kegiatan tersebut adalah bersih desa. Ada ungkapan dari kepala desa setempat tentang kegiatan bersama ini:

Kami biasanya mengadakan acara tahunan setiap bulan selo bentuknya adalah bersih desa. Dalam acara ini ada kegiatan doa bersama selama tiga hari. Acara satu hari untuk umat Islam kemudian satu hari lagi untuk umat Katolik dan ditutup pada hari terakhir doa dari sesepuh desa. Acara ini kami jalankan secara rutin dan setiap umat beragama yang berbeda kami beri waktu dan tempat untuk memanjatkan doa sesuai dengan keyakinannnya masing-masing. ${ }^{24}$

Bentuk kegiatan seperti ini adalah kegiatan untuk merekatkan dan menjaga solidaritas bersama. Masing-masing keyakinan

${ }^{22}$ Dalam penelitian yang dilakukan oleh Benedict $\mathrm{R}$ Anderson, rasa untuk membela kultur jawa tersebut begitu kuat bahkan sampai pada tingkat chauvinisme kultural. Oleh karena itu jika ada komunitas yang kurang rasa jawanya dan lebih arab atau lebih Cina dan tidak megadaptasi budaya jawa, maka orang jawa lebih suka meninggalkannya daripada melakukan relasi dengannya. Lihat Benedict R O'G Anderson, Mitologi Dan Toleransi Orang Jawa. Pengantar McT. Kahin (Yogyakarta: Qalam, 2000), 8.

${ }^{23} \mathrm{Hal}$ ini berbeda dengan relasi sosial yang ada pada masyarakat Klepu Kecamatan Sooko Kabupaten Ponorogo. Di Desa tesebut muslim dan Katolik jumlahnya hampir seimbang. Norma agama di masyarakat setempat menjadi ruang sosial pula, hal ini ditandai oleh hadirnya masyarakat setempat, baik itu Islam dan katolik pada acara Yasinan dan Tahlil. Batas antara dua agama tersebut tidak ada untuk ruang agama masing-masing.

${ }^{24}$ Wawancara, 02 Agustus 2017. 
diberi ruang yang semestinya untuk mengaktualisasikan apa yang diyakininya. Sehingga dalam ruang-ruang tersebut eksistensi keyakinan tetap terpelihara. Pemeliharaan seperti ini pada hakikinya juga sebagai model bagi menguatnya eksistensi norma susila.

Dalam ruang yang lain, seperti pemerintahan desa, komposisi perangkat desa juga menunjukkan variasi pemeluk agama. Hal itu seperti ditunjukkan dalam pengaturan perangkat desa yang terdiri dari muslim dan Katolik. Kepala desa beragama Islam, carik beragama Katolik berikut juga perangkat lainnya. Profesionalitas dan segi kemampuan lebih diutamakan dari pada kesamaan agama.

Dalam wawancara dengan perangkat desa Caluk ini, penulis tidak menemui secara personal dengan perangkat setempat melainkan dengan beberapa personel desa antara lain Carik Desa tersebut dan tiga orang lainnya. Semua perangkat ini berasal dari agama Katolik. Dalam wawancara tersebut ada ungkapan dari pak Carik desa tersebut yang mengatakan:

Kami di sini agamanya beragam mas, pak lurah sendiri agamanya Islam, nah saya sendiri Katolik. Dua bapak di depan sampean itu juga katolik. Dalam agama di pemrintahan desa ini beragam mas dan tidak ada masalah apa-apa sejak dari dulu. Semua saling menghargai antara satu dengan yang lain. Untuk apa lo mas mempersoalkan agama, yang penting kerja yang benar dalam menjalankan pemerintahan desa ini, terus diberi kesehatan, ketentraman, dan rizqi yang cukup. La dari pada membicarakan agama yang ujung-ujungnya konflik kan malah tidak menentramkan. Lebih baik tidak usah dipertentangkan.

Pak Sutonowo (kepala desa) sendiri beragama Islam, kakaknya beragama Katolik. Toh biasa-biasa saja. Hidupnya juga rukun-rukun saja. Dan begitu itu di sini banyak mas yang satu keluarga beragama berbeda. Malahan di desa ini waktu acara bersih desa, dua agama juga dikasih waktu yang berbeda untuk doa bersama agar desa ini diberi ketentraman.

Ungkapan dari pak Carik yang disepakati oleh perangkat lainnya ini adalah indikator yang jelas bahwa masalah perbedaan agama bukan sesuatu yang urgen. Bahkan perbedaan tersebut sudah menjadi bagian dari kultur desa. Karena menjadi bagian dari kultur tersebut, maka keberagamaan tersebut tidak menjadi sub dari narasi budaya besar. Kendati ada perbedaan dalam keluarga tentang masalah penanaman agama untuk masing-masing anak mereka tapi 
ketika mereka harus berhadapan dengan masyarakat secara luas, sub tersebut lebur dalam budaya besar yang ada.

Dalam kaitannya dengan budaya besar ini, adalah persoalan cara mereka bertahan hidup di desa tersebut. Cara bertahan hidup ini berkaitan dengan masalah pekerjaan sebagai pondasi bertahan hidup. Dalam pekerjaan, mereka rata-rata adalah tani dan buruh tani. Cara hidup ini menunjang terhadap terciptanya budaya besar karena dalam cara mereka bertahan hidup itu satu sama lain saling bergantung.

Relasi saling bergantung antara satu dengan yang lain dalam proses mengelola jalannya kehidupan seperti sambatan ketika musim tanam, kebutuhan tenaga kerja seperti buruh tani oleh petani, gotong royong untuk membangun perbaikan sarana-dan sarana desa, kebutuhan keamanan desa dengan melalui pos ronda, adalah kebutuhan-kebutuhan dasar yang terus mereka hadapi dalam kehidupan mereka. Persoalan-persoalan tersebut menumbuhkan saling bergantung antara satu dengan yang lain sehingga mengabaikan persoalan keyakinan dasar mereka akan agama.

Persoalan-persoalan hidup itu kemudian menumbuhkan narasi besar budaya mereka untuk hidup saling bargentung antara satu dengan yang lain sehingga persoalan sub-budaya lebur dalam kancah budaya besar. Proses meleburnya budaya sub menjadi budaya besar ini akhirnya menjadikan persoalan perbedaan menjadi bagian saja dalam budaya mereka. Fakta tentang pentingnya masalah survive (bertahan hidup) ini sebagaimana ungkapan pak Carik yang mengatakan," Untuk apa lo mas mempersoalkan agama, yang penting kerja yang benar dalam menjalankan pemerintahan desa ini, terus di beri kesehatan, ketentraman, dan rizqi yang cukup". Ungkapan "untuk apa mempersoalkan agama, yang penting kerja yang benar dan diberi kesehatan, ketentraman, dan rizqi yang cukup" ini adalah bentuk dari lebih pentingnya persoalan cara bertahan hidup.

Dalam norma kesopanan, siapa diri kita, apa agama yang sedang kita yakini, bukan menjadi persoalan penting. Yang utama dalam norma ini adalah bagaimana sikap kita kepada kelompok lainnya yang kelompok itu terkait dengan diri kita dalam soal bertahan hidup. Jika kita lebih mempersoalkan masalah primordialitas kita di atas cara kita bertahan hidup maka dengan sendirinya akan mengancam eksistensi ke dirian kita sendiri. 
Dalam norma susila juga demikian halnya. Norma susila lebih mengutamakan persoalan perasaan kita ketika kita menghadapi orang lain. Jika persoalan primordialitas itu ada dalam sikap kita, yang kemudian mengabaikan persoalan budaya besar tersebut maka stigma buruk akan serta merta tertuju pada diri kita. Sehingga harmonisasi itu menghilang. Dari sini kemudian menumbuhkan penyingkiran dan dislokasi. ${ }^{25}$ Dengan demikian cara mereka bertahan hidup itu melahirkan narasi budaya besar yang kemudian dari situ tumbuhlah norma susila dan norma kesopanan.

\section{PENUTUP}

Dari deskripsi tentang bentuk-bentuk norma yang mengubah primordialitas menjadi universalitas tersebut di atas, maka bisa ditarik kesimpulan:

Pertama, primordialitas agama pada hakikinya tidak hilang keberadaanya dalam kehidupan masyarakat Caluk. Ia masih merupakan bentuk yang punya fungsi dan ada secara nyata. Namun dalam masyarakat desa tersebut adabentuk-bentukpemilahan tentang kehidupan, yang menjadikan keberlangsungan primordialitas itu tidak menjadi ancaman terhadap universalitas yang ada. Pemilahan tersebut adalah terpolanya kehidupan primordialitas agama dalam ruang privat. Sedangkan dalam ruang publik, relasi masyarakat yang didasarkan pada pertanian membentuk ikatan persaudaraan tersendiri. Hal inilah yang kemudian menjadikan agama berubah sikap primordialitasnya. Kenyataan-kenyataan hidup sehari-hari itu kemudian menjadikan agama telah berubah menjadi universal.

Kedua, Karena adanya pemilahan antara ruang privat dan ruang publik, maka modus eksistensi dari norma juga mempunyai ruang ruang tersendiri. Norma agama beredar pada wilayah privat dan norma susila dan kesopanan berada dalam ruang publik. Adapun lembaga-lembaga yang menaunginya juga berbeda-beda. Norma agama ternaungi dalam ruang privat seperti keluarga dan masjid sedangkan norma susila dan kesopanan terwujud dalam ruang publik seperti politik dan kemasyarakatan.

${ }^{25}$ Dislokasi adalah perasaan terasing dengan lingkungannya sendiri. Hal ini terjadi karena orang tersebut mengabaikan budaya besar dan lebih mengutamakan sub-budaya. Akibat dari dislokasi adalah penyingkiran terhadapnya. Sikap yang kemudian muncul adalah ekstrimitas. 


\section{DAFTAR RUJUKAN}

Abdurrahman Wahid, Pergulatan Agama, Budaya, Dan Agama, Jakarta: Desantara, 2001.

Abdurrahman Wahid, Pergulatan Negara, Agama, Dan Kebudayaan, Jakarta: Desantara, 2006.

Abdurrahman Wahid, Islamku Islam Anda Dan Islam Kita, Jakarta: The Wahid Istitut, 2008.

Ahmad Baso, "Islamisasi Dan Pribumisasi: Nurcholis Madjid dan Abdurahman Wahid" dalam NU Studies: Pergolakan Pemikiran Antara Fundamentalisme Islam Dan Fundamentalisme Neo-Liberal, Jakarta: Erlangga, 2006.

Ahmad Baso, NU Studies: Pergolakan Pemikiran Antara Fundamentalisme Islam dan Fundamentalisme Neo-LiberalJakarta: Erlangga, 2006). hal 266-300.

Ahmad Baso,"Analisis Dekonstruktif Terhadap Radikalisme Islam: Dari Nalar Islam Pusat Menuju Identitas Islam Pribumi" dalam jurnal KALAM IAIN Raden Intan Lampung ISSN: 0853-9510 Vol.8 No.02 Desember 2014.

Ahmad Lutfi, Praktek-Praktek Kebenaran Agama: Analisis kontestasi Muslim Di Hadapan Katolik di Desa Klepu Kecamatan Sooko Kabupaten Ponorogo. Makalah proses terbit.

Ahmad Zainul Hamdi, Meraba Konflik Umat Beragama: Tragedi Kabel Mik (Jakarta: The Wahid Institut, 2008.

Amin Abdullah, "The Intersubjective Type of Religiosity: A Contribution (a fresh Ijtihad) of Indonesian Islamic Studies to a Multicultural Society". Makalah yang dipresentasikan dalam forum AICIS ke IV di Balikpapan tahun 2014.

Amin Abdullah, "Intersubjective Type Of Religiosity: A Contribution (a fresh Ijtihad) of indonesion Islamic Studies to A Multicultural Society". Makalah AICIS XIV Balikpapan 2014. 
Andrew Milner, Re-Imagining Cultural Studies: The Promise Of Cultural Materialisme, British: Sage Publikation, 2002.

Azumardi Azra, Renaisans Islam Asia Tenggara: Sejarah Wacana Dan Kekuasaan, Bandung: PT Reamaja Rosdakarya, 1999.

Benedict R O'G Anderson, Mitologi Dan Toleransi Orang Jawa. Pengantar McT. Kahin, Yogyakarta: Qalam, 2000.

Brian Morris, Antropological Studies Of religion:Introduction Text, Cambridge: Cambridge University Press, 1987.

Charles J Adam dalam bukunya Richard C. Martin (ed), Approaches To Islam In Religious Studies. Essay Richard C. Martin,"Islam And Religious Studies: An Introductory Essay", U.S.A: The University Of Arizona Oress, 1985.

David Kaplan Dan Albert Manner, Teori Budaya, Yogyakarta: Pustaka Pelajar, 1999.

Dhesi Haryanto, "Integrasi Antar Umat Beragama Di Desa Klepu Kecamatan Sooko Kabuoaten Ponorogo". Skripsi Universitas Muhammadiyah Ponorogo.

E.C Cuff And G.C.F Payne With D.W Francis, D.W Hustler And W.W. Sharrock (ed), Perpectives In Sociology. Second Edition, U.S.A: George Allen And Unwin Publisher, 1984.

Elly M. Setiadi Dan Usman Kolip, Pengantar Sosiologi, Pemahaman Fakta Dan Gejala Permasalahan Sosial: Teori, Aplikasi, Dan Pemecahannya. Cet ke II, Jakarta: Kencana Prenanda Media Group, 2011.

Emile Durkheim, The Rules Of Sociological Method, New York:The Free Press, 1964.

Emile Durkheim, Elementary Form Of Riligious Life. Translated And With An Introductory By Karen E. Field (New York: The Free Press, 2005.

Emile Durkheim, Suicide, New York: The Free Press, 1951.

Erwin Yudhi Prahara, Pengaruh Pendidikan Agama Pada Anak Dalam Keluarga Beda Agama Di Desa Klepu Kecamatan Sooko Kabupaten Ponorogo". Jurnal Cendekia. 
Emile Durkheim, The Rule Of Sociological Method, New York: the free press, 1964.

George Ritzer, Sociology: A Multiple Paradigm Sicience. Revised edition, London: Allyn And Bacon Inc, 1980.

Harun Nasution, Islam Rasional: Gagasan Dan Pemikiran. cet ke IV, Bandung: Mizan, 1996.

http://id.wikipedia.org/wiki/ferdinand_T\%C3\%B6nnies tanggal 20 agustus 2017 jam 09.00 WIB.

http://www.sindopos.com/2016/02/profil-desa-kelurahan-desacaluk.html, yang diakses pada tanggal 06 september 2017 jam 09.53 WIB.

Imam Suprayogo dan Tabrani, Metodologi Penelitian, Bandung: PT Remaja Rosdakarya, 2003.

Jose Casanova, Publik Religions In The Modern World, Chicago: The University Of Chicago Press, 1994.

Lexy J. Moleong, Metodologi Penelitian Kualitatif, Bandung: PT Remaja Rosdakarya, 2009.

Maksum, "Kerukunan Antar Umat Beragama Islam Dan Katolik Di

Desa Klepu Kecamatan Sooko Kabupaten Ponorogo". Tesis Pasca Sarjana Universitas Islam Negeri Sunan Kalijaga Yogyakarta.

Marwan Shalehudin, "Konservasi Budaya Lokal Dalam Pembentukan Harmoni Sosial (Studi Kasus Di Desa Klepu Sooko Kabuoaten Ponorogo)". Jurnal Multikultural Dan Multireligius, Vol IX No 34.

Muhammad Syahrur, al-Islam wa al-Iman Mandhumat al-Qiyam, Damasqus: 1996.

Noeng Muhajir, Metodologi Penelitian Kualitatif. Edisi III, Yogyakarta: Rake Sarasin, 1998.

Nurkholis Madjid, Islam Doktrin Dan Peradaban, Jakarta: Paramadina Mulya, 2005.

Nurkholis Madjid, Kaki langit Peradaban Islam, Jakarta: Paramadina Mulya, 1997. 
Nurkholis Madjid, Dialog Keterbukaan: Artikulasi Nilai Islam Dalam Wacana Sosial politik Kontemporer, Jakarta: Paramadina, 1998.

Richard C. Martin (ed), Approaches To Islam In Religious Studies. Essay Richard C. Martin,"Islam And Religious Studies: An Introductory Essay", U.S.A: The University Of Arizona Oress, 1985.

Ridwan Abdullah, Mengenal Kearifan Lokal Di Desa Klepu: Praktil Hubungan Sosial Lintas Agama Dan Mekanisme Pencegahan Konflik. 2008.

Sigit Nurcahyo, "Pendidikan Agama Pada Anak Dalam Keluarga Beda Agama (Studi Kasus Di Desa Caluk Kecamatan Slahung Kabupaten Ponorogo). Skripsi Jurusan Tarbiyah Stain Ponorogo Tahun 2016.

Suharsimi Arikunto, Prosedur Suatu Pendekatan Praktek, Jakarta: Rieneka Cipta, 1993.

Suryana P.N. Awangga, Desain Proposal Penelitian Panduan Tepat Dan Lengkap Membuat Proposal Penelitian, Yogyakarta: Piramid Publiser, 2007. 